\title{
A POSSIBLE RECORD OF DEATH-FEIGNING IN A TOAD
}

by Robert W. Nero, Manitoba Museum of Man and Nature, Winnipeg

On May 21, 1967, while I was walking with my sons in an open sandy spot on a ridge adjacent to dry marshland in the Delta, Manitoba area, a toad was observed to behave in a manner that seems unusual enough to be worth recording. Upon turning over a flat piece of wood we discovered a toad about an inch long squatting in an exposed, shallow cavity. The toad, which was evidently in a burrow beneath the board, was closely surrounded by sand and, until we lifted the roof off its house, was clearly safe and snug. It took a moment to identify the small, brownish object in the cavity as a toad, for it was sitting with its legs drawn up tightly to its body. When touched, it immediately, and much to my surprise, stiffened out as if suddenly stricken. Both pairs of legs were fully extended backwards, the entire body was rigid, the eyes were closed, and, except for slight breathing movements at long intervals, the toad appeared to be dead. It remained in this state, while held in my son's hand as we walked along, for nearly two minutes. It then resumed a more usual posture, with open eyes and regular breathing movements, and appeared to be none the worse for its apparent seizure.

I thought the toad had perhaps reacted physiologically to the sudden exposure to light and heat when we uncovered it, for it was an unusually warm, dry afternoon. However, there are behaviourisms reported in the literature for certain toads that suggest that this may have been an observation of an adaptive behaviour pattern. G. Kingsley Noble (1931Dover reprint, 1954. The biology of the amphibia. McGraw-Hill Book Co., Inc., N.Y. 577 pp.) describes an "unken" reflex behaviour in the European Fire-bellied Toad (Bombina bombina), stating (p.380): "The typi- cal unken reflex is characterized not only by a distinctive posture of immobility but also by a closure of the eyes, a slowing down of the respiratory movements, and an increase in the skin secretion." However, although Bombina goes into this reflex "if suddenly disturbed", it "will bend its head and legs sharply back over the body and turn the ventral surfaces of its forearms upward." This anuran is brightly colored underneath and this posture exposes this coloration, presumably to warn potential predators that it is the unpalatable Bombina. He also says that some ather species show the reaction, "various European species of Rana and Bufo exhibit more or less of the reaction. ... The Bullfrog, Rana catesbeiana, if cornered, will sometimes thrust out its arms and flatten its body. The back is not curved upward as in Bombina, but otherwise the reaction has a considerable resemblance to the unken reflex. At low temperatures the reflex of Bombina is incomplete and resembles that of Rana..."

Noble further suggests (p.381) that the "unken" behaviour may be a simple reflex response not involving the higher centers of the brain. The response is greater in the female than in the male, and it "may have some significance in the mating process, a vigorous grip of the male tending to throw the female into a state of tonic immobility and thus prevent her escape." Our specimen, which was a Canadian Toad (Bufo hemiophrys), has been identified by Harvey Beck as a female. It may be that touching the toad unexpectedly elicited a reflex response of unusual extremity that is rarely observed.

Noble also states (in the same book, p.424) a "death feint" or state of "tonic immobility" is not uncommon in salamanders, frogs, and toads, and may be a protective measure. It may 
last a few minutes or "it may be prolonged over an hour if disturbing sensory impressions are avoided." Writing of the six-weeks-old young of the American Toad (Bufo americanus), Mary C. Dickerson (1906. The frog book, North American toads and frogs with a study of the habits and life histories of those of the northeastern states. Doubleday, Page \& Co., N.Y. 253 pp.), stated (p.71): "When they are handled they play dead for seconds at a time and finally 'come to life' sticking up their little orange paws in most ridiculous fashion before they tumble over and hop away ...." Later, speaking of the adul.ts, she states (p.87): "Let an enemy seize him roughly, and he is a dead toad.
'Playing dead' saves him many a time. He will lie on his back with scarcely any perceptible motion for minutes at a time ... Even the breathing movements seem to be suspended." In none of the above situations, however, are the legs extended backwards as was the case in our observation.

Neither Francis R. Cook, Curator of Herpetology, National Museum of Canada, nor Richard W. Sutton, Chief, Division of Exhibits and Interpretation, Manitoba Museum of Man and Nature, reports having observed a reaction in a toad of the kind reported here. I am indebted to both of the latter for suggesting reference sources.

\section{STRAWBERRIES}

by Keith F. Best, Swift Current

Strawberries are low, apparently stemless, perennial herbs with underground, scaly rootstocks; they also have runners, which root at every second node, producing new plants. Our most common strawberry is the smooth wild strawberry, Fragaria glauca, which occurs in low spots on prairie, open woodlands and moist areas. The numerous basal leaves are composed of three toothed leaflets and the rather long leafstalks are sheathed at the base by a pair of membranous bracts. The flowers are white and borne on leafless stems. The numerous short, seed-producing organs (pistils) are borne on a cone-shaped, fleshy receptacle. The pistils, ripening into small, hard "seeds" (achenes), persist on the receptacle, which becomes pulpy and enlarged to form the familiar edible "berry".

The genus Fragaria belongs to the rose family (Rosaceae), and this name comes from the Latin fragum, strawberry, a word derived from fragans, alluding to the attractive odor of the fruit. The origin of the common name strawberry is somewhat obscure. Many authorities derive it from the Anglo-Saxon streawberige (streaw, straw, and berige, berry), which they claim for the resemblance

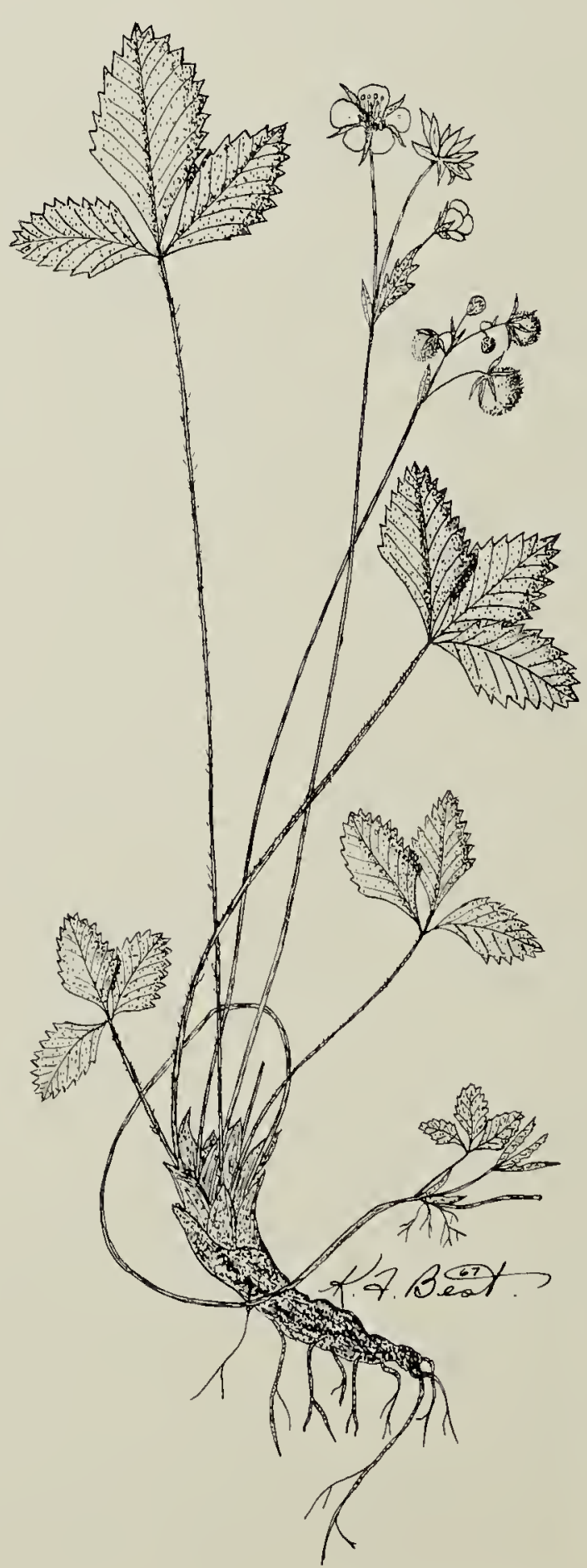

THE BLUE JAY 